\title{
The Efforts of Talang Mamak Indigenous People to Maintain Their Existence in Customary Forest Resources Battle
}

\author{
Rizky Octa Putri Charin ${ }^{1}$, Arief Hidayat ${ }^{2 *}$ \\ 1, 2 Department of Politics and Government, Gadjah Mada University, Yogyakarta, Indonesia \\ *Corresponding Author: ariefcrbn@gmail.com
}

\section{ARTICLE INFO}

Publication Info:

Review Articles

How to cite:

Charin, R. O., E Hidayat, A. (2019). The Efforts of Talang Mamak Indigenous People to Maintain Their Existence in Customary Forest Resources Battle. Society, 7(1), 21-36.

DOI : $10.33019 /$ society.v7i1.78

Copyright (C) 2019. Owned by Author(s), published by Society

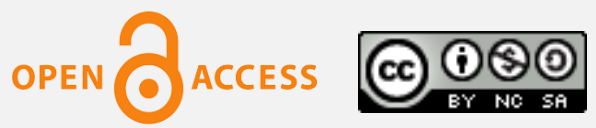

This is an open access article.

License: Attribution-

NonCommercial-ShareAlike (CC BY-NC-SA)

\section{ABSTRACT}

The resources of Customary Forest play an important role in Talang Mamak Indigenous People to survive. The exploitation of the forest by private companies and investors has caused violent conflict. The situation of the indigenous people becomes worsen since the local government does not fully protect their rights of the forest. Even, the local government tends to defend private company and investor in addressing the conflict. Customary forest of Talang Mamak indigenous people is in the oligarchs grip and conflict of interest with their elder. The Indigenous people are in crossroad; to preserve or to release their heritage and right. This study aims to determine the efforts of Talang Mamak Indigenous People to maintain their existence in the customary forest resources battle with private company and investor. This study used qualitative descriptive method. The data collection were documentation analysis and other relevant literature. This study used Theory of Oligarchy (Winters 2011) as grounded theory. The result found that the efforts of the indigenous people to fight for their rights getting weak. Some of them begin to accept compensation from the company and investor, in other word, some of them are willing to release their heritage and right on the forest.

$\begin{array}{ll}\text { Keywords: } & \text { Customary Forest; Oligarchy; Private } \\ & \text { Company; Resources; Talang Mamak } \\ & \text { Indigenous People; }\end{array}$




\section{Introduction}

Conflict on customary forest exploitation of Talang Mamak Indigenous people is not only with private company but also several new entities such as the local elite and the government.

Local Elite, The indigenous chief and the village head, acts as a broker trading the customary land to private company for personal gain without permission of the community. This is a strategy of private company and capital owner to take over indigenous forest resources. Not only land grabbing for plantation area expansion, but companies engaged in paper production also do illegal logging.

This study discusses about the conflicts between Talang Mamak indigenous people who live in Indragiri Hulu, Riau Province and private companies engaged in palm oil and paper production. Both the people and the companies have struggled for ulayat land since the beginning of 2000 and ending in 2017.

Since the indigenous people have loss their customary land and forests, they are increasingly losing economic resources, traditional wealth and culture.

By investigating the dynamics of the conflict occurred between private companies, investor, and the indigenous people in early 2000 to 2008 , and comparing it with the development of conflicts in the end of 2010 until 2015, this study aims to discover the efforts of Talang Mamak Indigenous people to maintain their existence in customary forest resources battle.

\section{Theoretical Framework}

\section{Theory of Oligarchy: Customary forest tenure Local Elite shifting}

Jeffrey A. Winters, in his book entitled Oligarchy, states that oligarchs were viewed as empowered by wealth for centuries. The common thread for oligarchs across history is that wealth defines them, empowers them and inherently exposes them to threats. The existential motive of all oligarchs is wealth defense. How they respond varies with the threats they confront, including how directly involved they are in supplying the coercion underlying all property claims and whether they act separately or collectively. These variations yield four types of oligarchy: Warring, ruling, sultanistic and civil.

Related to this study, the indigenous chief of Talang Mamak plays a rule as warring category, if at first the power in the form of coercion from the Indigenous Chief or indigenous used for collective interests such as maintaining land claims or other resources shared with other dominant actors as common enemies, it can then be used to make wealthy enriching and strengthening individuals or groups as chief, who maintain and control their own groups first and then others around whom they succeed in defeating 1 . Although it will eventually be concentrated only under individual control, material power is initially organized into "collective social power" because it is based on resources in the form of village assets, small clans, and families, which are prepared and maintained as "together". The legitimacy of the Indigenous Chief or village head is exploited arbitrarily, the claim of these resources will implicate for the material resources united over individual ownership rather than the collective. In other words, the expression "ours" becomes "mine".
1 Jeffrey A. Winters. 2011. Oligarchy. Jakarta: PT. Gramedia Pustaka Utama. p. 64

Copyright (C) 2019. Owned by Author(s), published by Society. This is an open-access article under CC-BY-NC-SA license. https://doi.org/10.33019/society.v7i1.78 


\section{Theory of Conflict Approach}

Conflict means perceived divergence of interest, a belief that the parties current aspirations are incompatible (Pruit and Rubin, 2009). the power of oligarchs will immerse conflicts among the indigenous people with private companies have been related each other.

\section{Research Methodology}

This study used qualitative method with descriptive. Sugiono (2008: 15) states that it is in constructive paradigm research design and the researcher is a key instrument when the study conducted in natural objective. The data sources were media, related research articles, and legislation. Data collection were analyzed as it reflected on the title. Data Validation test and information of this study based on specific criteria; data validation and level of trust in describing finding and discussion, conclusion, and explanation. This study used data as comparison for various information by organizing, compiling into pattern and category, and interpret them using some schema.

\section{Discussion and Result}

\section{A brief history of Talang Mamak Indigenous People in Riau}

The indigenous entity live along the Indragiri River, Indragiri Hulu district, Riau Province. This tribal community belongs to the Old Malay race (Proto Malay). The customary forest area reaches around 400,000 hectares and it has been approved by the Dutch colony through the Resident of Indragiri in $1925^{2}$. The Talang Mamak

\footnotetext{
2 Court Decision Number 35/PUU-X/2012 about Constitutional Review Number 41 Year 1999 about Forestry in The 1945 State Constitution of the
}

people is an Indragiri Indigenous community and often calls themselves as Tuha people, means the first men live in Indragiri Hulu. Their distribution Riau is spread in four sub-districts, they are in Batang Cenaku Sub-district, Kelayang Subdistrict, Seberida Sub-district, and Batang Gasal Sub-district. Two sub-districts, Kelayang and Batang Cenaku Sub-districts, covered 17 villages specifically in Talang Mamak has two Communities: Firstly, Talang Mamak Tiga Balai Community Area in Kelayang District, Secondly, Malay Community Area in Batang Cenaku in Batang Cenaku District ${ }^{3}$.

Their livelihood is farming and planting especially rubber plantation. Rubber is main commodity of the community. Before that, since the beginning of the 19th century the forest products are varies, like dragon's blood palm dragon (Daemonorops didymophylla Becc), jelutung (Dyera costulata), red / white balam (Shorea balangeran) and aloes tree (Aloidendron barberae) and rattan (Calameae). The people income increases with demand for forest products. Rubber planting certainly makes them more settled and at the same time as a tool to maintain their land and forests. Forests are the main source of livelihood for the Talang Mamak indigenous people as their main livelihood, forests is a great cultural value for them. Land and forest as living areas are an inseparable part. Since hundreds of years

Republic of Indonesia. The Constitutional Court of the Republic of Indonesia. P. 102

${ }^{3}$ Gilung. Talang Mamak: Hidup Terjepit Di Atas Tanah dan Hutannya Sendiri-Potret Konflik Kehutanan Antara Masyarakat Adat Talang Mamak Di Kabupaten Indragiri Hulu, Provinsi Riau Dengan Industri Kehutanan. Presented as additional material witnesses on Constitutional Court Review No.41 year 1999 about forestry in The 1945 State Constitution of the Republic of Indonesia at Constitutional Court of the Republic of Indonesia, June 14, 2012, p. 2 
ago, the community has become unity with nature. The environment in which they live is regulated through customary law, and the management decision is regulated by Patih or the indigenous chief who is the highest power for Talang Mamak under the Indragiri Sultanate.

The importance of forests for their life has been loudly delivered by one of the chief named Laman; "I'd better be shot dead, than the customary forest runs out". Forest which is a communal property, in terms of its arrangement is carried out by a Patih which is a symbol of the highest power of the community. There is an old saying that is well-known among them : "it is better a child dies, rather than tradition". It indicates that their identity cannot be separated from customary forests managed by customary law under the supervision of Patih.

\section{Rights of Talang Mamak Indegenous People on Lands}

The first chief of the Talang Mamak Community was Datuk Patih Nan Sebatang, in beliefs as oral tradition, their ancestors gave three regions as inheritance for their children and grandchildren, they are the Talang Parit area which means land where trenches (streams), Talang Perigi where in that area there are perigi (wells) and Talang Durian Jajar which means there are durian planted in raw in the region as customary boundaries.

The community has measured their Indigenous Forests which are bordered by trenches, perigi and durian lanes which still exist today, with the total area of customary forests is 451,411 hectares. This customary land ownership was also recognized by Haji Indragiri Hulu, the king in the past and documented in the Resident of Indragiri in 1925.

\section{Dynamics of Conflict: Talang Mamak Indigenous People and Palm Oil Plantation Company}

The conflicts of land between Talang Mamak Indigenous People to claim their customary forest and the company occurred complicatedly. From year 2000 to 2007, the indigenous people made various efforts to stop the companies that were considered to occupy the customary forests of the Talang Mamak indigenous, such as throwing stones at the operational vehicles of private companies, asking for "road money" to drivers of private companies operating vehicles ${ }^{4}$. According to James C. Scott, The efforts are a form of resistance from those who lose. He examines the lives of farming communities in the Sedaka area (not real name) in the State of Kedah, Malaysia, with the aim of observing the lives of farmers and the form of "daily resistance" that occurs. Resistance takes place with unique forms, resistance is not in a structured form, but in the form of small daily resistance such as small-scale stealing, slowing down, pretending to be sick, pretending to be stupid, swearing behind, pretending to agree, and doing sabotage at night ${ }^{5}$. The resistance carried out is not in a massive and structured form, but only in the form of small resistance from those who are powerless and not so capable of destabilizing the group of private companies as "winners". The indigenous people of the Talang Mamak indigenous people take on the role of "losers", namely those who do not have power, must carry

\footnotetext{
4 MongabayIndonesia.com. Talang Mamak Hak Ulayat Musnah Diterjang Budaya Uang. Accessed from http://www.mongabay.co.id/2013/01/19/talangmamak-hak-ulayat-musnah-diterjang-budaya-uang/ on December 17, 2018, on 13.20 WIB

5 C. Scott, James. 2000. Senjatanya Orang-Orang Yang Kalah, (Bentuk-bentuk Perlawanan Sehari-Hari Kaum Tani). Jakarta: Yayasan Obor Indonesia. p. 318
} 
out "daily resistance" to continue their lives while avoiding greater risks. The resistance to be understood if it traces the conflict between the community and private companies which have grabbed the customary forests. When compared with the strength of the company, the resistance action did not bring any impacts. As Scott explained, they ask for money for the drivers of the company's operational vehicles just to guarantee their survival is threatened because of private companies presence that seize the forest and land that initially became their place of life.

\section{Dynamics of Conflict occurrence were as followed 6 :}

Table 1.

Dynamics of Conflict between Indigenous People and Company in 2019

\begin{tabular}{|c|c|c|c|c|}
\hline Years & Incidents & Triggers & Parties Involved & Results or Loss \\
\hline 2000 & $\begin{array}{l}\text { Marched to against } \\
\text { Regunas Agri Utama } \\
\text { Ltd (PT. RAU) to } \\
\text { expand Oil Palm } \\
\text { Plantation area }\end{array}$ & $\begin{array}{l}\text { PT Regunas Agri Utama (PT. } \\
\text { RAU) opened new land about } \\
\text { 10,000 ha for oil palm plantation } \\
\text { in three locations, they are } \\
\text { Talang Selantai village, Talang } \\
\text { Perigi village and Talang Durian } \\
\text { Cacar village. The locations are } \\
\text { Ulayat land, customary land of } \\
\text { Talang Mamak Indigenous } \\
\text { Community }\end{array}$ & $\begin{array}{l}\text { Talang Mamak } \\
\text { Indigenous People } \\
\text { vs PT. RAU, this } \\
\text { conflict were } \\
\text { mediated by DPRD } \\
\text { Indragiri Hulu }\end{array}$ & $\begin{array}{l}\text { Indigenous People } \\
\text { marchedin the offices of } \\
\text { regional house of } \\
\text { representatives and } \\
\text { Indragiri Hulu head of } \\
\text { sub-district. The people } \\
\text { demanded the } \\
\text { plantation as theirs. } \\
\text { DPRD suggested PT } \\
\text { RAU to give the } \\
\text { indigenous people new } \\
\text { land which can be } \\
\text { planted oil palm as they } \\
\text { need. However, the } \\
\text { people refused it. }\end{array}$ \\
\hline July 2002 & $\begin{array}{l}\text { Conflicts occured in } \\
\text { village of Talang } \\
\text { Sungai Limau Rakit } \\
\text { Kulim Indragiri Hulu } \\
\text { subdistricts }\end{array}$ & $\begin{array}{l}\text { National Land Agency (BPN) } \\
\text { Indragiri Hulu issued land } \\
\text { certificate about the conflicts } \\
\text { between private company and } \\
\text { Indigenous people for land } \\
\text { battles about } 200 \text { Ha in } 1.056 \mathrm{Ha} \text {, } \\
\text { land area of Inecda Plantation } \\
\text { Ltd which handed over } \\
\text { ownership to Mega Nusa Inti } \\
\text { Sawit, Ltd. Indigenous People of } \\
\text { Talang Sungai Limau argued } \\
\text { that they never had any } \\
\text { compentations on the } 200 \text { Ha. } \\
\text { Also there are no agreement with } \\
\text { Pola Inti Plasma maupun pola } \\
\text { PIR (Perkebunan Inti Rakyat). } \\
\text { The indigenous people have } \\
\text { clear certificate both land } \\
\text { certificate and right of Ulayan } \\
\text { land ownership }\end{array}$ & $\begin{array}{l}\text { Talang Mamak } \\
\text { Indigenous } \\
\text { community in } \\
\text { Talang Sungai } \\
\text { village vs Inecda } \\
\text { Plantation Ltd. and } \\
\text { Mega Nusa Inti } \\
\text { Sawit, Ltd }\end{array}$ & $\begin{array}{l}\text { Review on land } \\
\text { certificate issued by } \\
\text { BPN especially in } \\
\text { conflict land of } 200 \text { ha, } \\
\text { which has been grabbed } \\
\text { by . Mega Nusa Sawit, } \\
\text { Ltd as it land abudance } \\
\text { of Inecda Plantation,Ltd }\end{array}$ \\
\hline
\end{tabular}

${ }^{6}$ Johny Setiawan, et al. Laporan Final Penelitian: Analisa Konflik Pertanahan di Provinsi Riau Antara Masyarakat dengan Perusahaan. Research and Development Team FKPMR 2007. p. 89-103

Copyright ( $\mathrm{2}$ 2019. Owned by Author(s), published by Society. This is an open-access article under CC-BY-NC-SA license. 
The Efforts of Talang Mamak Indigenous People to Maintain Their Existence in Customary Forest Resources Battle

\begin{tabular}{|c|c|c|c|c|}
\hline Years & Incidents & Triggers & Parties Involved & Results or Loss \\
\hline $\begin{array}{c}\text { November } \\
2002\end{array}$ & $\begin{array}{l}\text { Audiences to DPRD } \\
\text { Indragiri Hulu and } \\
\text { regent of Bupati } \\
\text { Indragiri Hulu }\end{array}$ & $\begin{array}{l}\text { Mega Nusa Inti Sawit Ltd and } \\
\text { the Talang Sungai Limau Village } \\
\text { people visited the Indragiri Hulu } \\
\text { DPRD office. In the same month } \\
\text { they met the Regent through the } \\
\text { Regional Secretary of Indragiri } \\
\text { Hulu. }\end{array}$ & $\begin{array}{l}\text { People of Talang } \\
\text { Sungai Limau } \\
\text { village and Mega } \\
\text { Nusa Inti Sawit, Ltd }\end{array}$ & $\begin{array}{l}\text { Regent of Indragiri Hulu } \\
\text { issued a letter so that } \\
\text { Mega Nusa Inti Sawit, } \\
\text { Ltd. resolve cases of } \\
\text { land disputes with } \\
\text { indigenous peoples as } \\
\text { well as possible. }\end{array}$ \\
\hline 2004 & $\begin{array}{l}\text { The people of Talang } \\
\text { Sungai Limau Village } \\
\text { and Talang Sungai } \\
\text { Parit Village, Rakit } \\
\text { Kulim Subdistrict, } \\
\text { Indragiri Hulu } \\
\text { conducted a march on } \\
\text { Inecda Ltd. office. and } \\
\text { the office of the Regent } \\
\text { and the Indragiri Hulu } \\
\text { DPRD. }\end{array}$ & $\begin{array}{l}\text { Continuing conflict with Inecda } \\
\text { Plantation Ltd regarding the } \\
\text { control of } 200 \text { ha of land for the } \\
\text { company's oil palm plantations }\end{array}$ & $\begin{array}{l}\text { Inecda Plantation } \\
\text { Ltd vs people of } \\
\text { Talang sungai } \\
\text { Limau and Talang } \\
\text { Sungai Parit villages }\end{array}$ & No result \\
\hline 2004 & $\begin{array}{l}\text { people of Talang Sei } \\
\text { Parit and Talang Sei } \\
\text { Limau Villages, Rakit } \\
\text { Kulim Subdistrict, } \\
\text { Indragiri Hulu held a } \\
\text { demonstration in the } \\
\text { PTPN V company area }\end{array}$ & $\begin{array}{l}\text { The people claimed as land } \\
\text { owners of PTPN V area about } \\
1.700 \text { ha. }\end{array}$ & $\begin{array}{l}\text { PTPN V vs people } \\
\text { of Talang Sei Parit } \\
\text { and Talang Sei } \\
\text { Limau villages }\end{array}$ & No result \\
\hline June, 2006 & $\begin{array}{l}\text { Since 1997, Inecda Ltd } \\
\text { has built a new } 9000 \text { ha } \\
\text { oil palm plantation in } \\
\text { the communal land of } \\
\text { the Talang Mamak } \\
\text { indigenous community, } \\
\text { and they did not know } \\
\text { that presence }\end{array}$ & $\begin{array}{l}\text { Indigenous community refusal } \\
\text { on development of oil palm } \\
\text { Inecda Plantation Ltd about } 9000 \\
\text { ha }\end{array}$ & $\begin{array}{l}\text { People of Talang } \\
\text { Sungai Parit and } \\
\text { Desa Talang Sungai } \\
\text { Limau villages vs } \\
\text { Inecda Plantation, } \\
\text { Ltd }\end{array}$ & $\begin{array}{l}\text { The mediation with } \\
\text { DPRD Riau province, } \\
\text { FKPMR and WALHI but } \\
\text { no result }\end{array}$ \\
\hline $\begin{array}{l}\text { 2005- } \\
\text { September } \\
2006\end{array}$ & $\begin{array}{l}\text { In } 2002 \text { PT Bukit } \\
\text { Betabuh Sei Indah } \\
\text { obtained a business } \\
\text { permit for the } \\
\text { utilization of forest } \\
\text { products in the form of } \\
\text { timber and plantations } \\
\text { covering an area of } \\
13,450 \text { ha. In } 2005 \text { - mid } \\
2006 \text {, the company } \\
\text { destroyed the } \\
\text { community rubber } \\
\text { plantations and oil } \\
\text { palm plantations to } \\
\text { replace acacia plants. }\end{array}$ & $\begin{array}{l}\text { The community was angry and } \\
\text { took action to extract the acacia } \\
\text { planted on the communal land of } \\
\text { the Talang Mamak native } \\
\text { indigenous. }\end{array}$ & $\begin{array}{l}\text { Indigenous } \\
\text { Community vs PT. } \\
\text { Betabuh Sei Indah } \\
\text { Ltd }\end{array}$ & $\begin{array}{l}\text { The Indigenous People } \\
\text { Destructed acacia plants } \\
\text { owned by Beautiful } \\
\text { Batabuh Sei, Ltd }\end{array}$ \\
\hline
\end{tabular}

Copyright (C) 2019. Owned by Author(s), published by Society. This is an open-access article under CC-BY-NC-SA license. https://doi.org/10.33019/society.v7i1.78 
The Efforts of Talang Mamak Indigenous People to Maintain Their Existence in Customary Forest Resources Battle

\begin{tabular}{|c|c|c|c|c|}
\hline Years & Incidents & Triggers & Parties Involved & Results or Loss \\
\hline June 2005 & $\begin{array}{l}\text { Residents of Talang } \\
\text { Mamak, Talang Sungai } \\
\text { Limau Village, counted } \\
7 \text { times to visit the } \\
\text { DPRD office to } \\
\text { complain about the } \\
\text { looting of communal } \\
\text { land by PT Inecda } \\
\text { Platation covering 3,200 } \\
\text { Ha. Hundreds of times } \\
\text { residents came to the } \\
\text { Indragiri Hulu DPRD } \\
\text { office to ask for clarity. } \\
\text { But because the } \\
\text { Indragiri Hulu DPRD } \\
\text { did not provide } \\
\text { concrete solutions. The } \\
\text { community then } \\
\text { complained to the Riau } \\
\text { DPRD. Residents only } \\
\text { demand 1,600 hectares } \\
\text { of land from 3,200 } \\
\text { hectares of communal } \\
\text { land controlled by PT } \\
\text { Inecda }\end{array}$ & $\begin{array}{l}\text { The villagers demand that the } \\
\text { land owned by residents be } \\
\text { returned to an area of } 1,600 \text { ha }\end{array}$ & $\begin{array}{l}\text { Indigenous People } \\
\text { vs Inecda } \\
\text { Plantation, Ltd }\end{array}$ & $\begin{array}{l}\text { The mediation } \\
\text { agreement with Regent } \\
\text { of Indragiri Hulu, } \\
\text { Thamsir Rachman, } \\
\text { about } 1,600 \text { ha of land } \\
\text { managed by Inecda, Ltd } \\
\text { returned }\end{array}$ \\
\hline $2006-2007$ & $\begin{array}{l}\text { Talang Mamak } \\
\text { indigenous, Rakit } \\
\text { Kulim District and } \\
\text { Peranap Indragiri } \\
\text { Hulu. Conducting } \\
\text { demonstrations on } \\
\text { massive activities } \\
\text { taking place on their } \\
\text { land which took place } \\
\text { since } 2002 \text { by PT. Bukit } \\
\text { Betabuh Sei Indah } \\
\text { which is customary } \\
\text { forest }\end{array}$ & $\begin{array}{l}\text { The community demands the } \\
\text { return of the area because of its } \\
\text { status as ulayat forest, it cannot } \\
\text { be converted into Industrial } \\
\text { Plantation Forest (HTI) }\end{array}$ & $\begin{array}{l}\text { Indegenous } \\
\text { community vs Bukit } \\
\text { Sei Betabuh, Ltd }\end{array}$ & No result \\
\hline 2006 & $\begin{array}{l}\text { Indigenous Forests The } \\
\text { Talang Mamak } \\
\text { indigenous was } \\
\text { scheduled to } \\
\text { strengthen its legal } \\
\text { umbrella through } \\
\text { regional regulations in } \\
\text { accordance with the } \\
\text { Joint Decree (SKB) } \\
\text { Number } 31 \text { of } 2006 \\
\text { concerning the } \\
\text { Indigenous Forest of } \\
\text { the Talang Mamak } \\
\text { indigenous. }\end{array}$ & $\begin{array}{l}\text { The community wants } \\
\text { customary forests to be returned } \\
\text { to citizens with a more } \\
\text { comprehensive legal umbrella }\end{array}$ & $\begin{array}{l}\text { Indigenous people } \\
\text { vs Inecda, Ltd, } \\
\text { Bukit Sei Betabuh } \\
\text { Indah, Ltd and etc. }\end{array}$ & $\begin{array}{l}\text { Unrealized loss or no } \\
\text { result }\end{array}$ \\
\hline
\end{tabular}

Copyright (C) 2019. Owned by Author(s), published by Society. This is an open-access article under CC-BY-NC-SA license. https://doi.org/10.33019/society.v7i1.78 
The Efforts of Talang Mamak Indigenous People to Maintain Their Existence in Customary Forest Resources Battle

\begin{tabular}{|c|c|c|c|c|}
\hline Years & Incidents & Triggers & Parties Involved & Results or Loss \\
\hline 2007 & $\begin{array}{l}\text { A total of 13,450 } \\
\text { hectares of customary } \\
\text { land of the Talang } \\
\text { Mamak indigenous, } \\
\text { Peranap District and } \\
\text { Kulak Inhu Rakit were } \\
\text { taken over by PT Bukit } \\
\text { Betabuh Sei Indah }\end{array}$ & $\begin{array}{l}\text { The community refused to take } \\
\text { land by Bukit Betabuh Sei Indah } \\
\text { Ltd }\end{array}$ & $\begin{array}{l}\text { Indigenous People } \\
\text { vs Betabuh Sei, Ltd }\end{array}$ & No result \\
\hline 2008 & $\begin{array}{l}\text { SAL Ltd entered into a } \\
\text { cooperation agreement } \\
\text { with three village } \\
\text { heads, namely the } \\
\text { Head of the Selantai } \\
\text { Village, the Talang } \\
\text { Durian Cacar Village } \\
\text { Head and the Talang } \\
\text { Perigi Village Head. } \\
\text { Based on the } \\
\text { agreement, where PT. } \\
\text { SAL is allowed to } \\
\text { control a forest area of } \\
1000 \text { ha. }\end{array}$ & $\begin{array}{l}\text { The community refused it } \\
\text { because the community felt } \\
\text { disadvantaged by the system of } \\
\text { partnership initiated by the } \\
\text { company. }\end{array}$ & $\begin{array}{l}\text { Indigenous People } \\
\text { vs SAL, Ltd }\end{array}$ & No solution \\
\hline 2013 & $\begin{array}{l}\text { Conflict occurred } \\
\text { between the } \\
\text { community and } \\
\text { Perkebunan Nusantara } \\
\text { V Ltd, the company } \\
\text { promises to build an oil } \\
\text { palm plantation with a } \\
\text { KKPA pattern of } 680 \text { ha }\end{array}$ & $\begin{array}{l}\text { The community collects the } \\
\text { promise of PTPN V which will } \\
\text { empower the people by building } \\
\text { oil palm plantations covering } 680 \\
\text { ha }\end{array}$ & $\begin{array}{l}\text { Indigenous people } \\
\text { vs PTPN V }\end{array}$ & $\begin{array}{l}\text { in fact, they only built } \\
200 \text { hectares for six } \\
\text { thousand families of the } \\
\text { Talang Mamak } \\
\text { Indgenous Community }\end{array}$ \\
\hline
\end{tabular}

Source: data analysis of researcher, 2019. 


\section{A total of land area grabbed by Private Companies $^{7}$}

Tabel 2.

A total of land area grabbed by Private Companies in 2019

\begin{tabular}{|c|c|c|c|}
\hline Years & Incidents & $\begin{array}{l}\text { A total of } \\
\text { Land } \\
\text { grabbed by } \\
\text { Private } \\
\text { Company }\end{array}$ & Areas \\
\hline \multirow[t]{3}{*}{2003} & $\begin{array}{l}\text { Land } \\
\text { occupation } \\
\text { by Inecda } \\
\text { Plantation, } \\
\text { Ltd }\end{array}$ & 9000 ha & $\begin{array}{l}\text { Villages of } \\
\text { Talang Sungai } \\
\text { Parit and } \\
\text { Talang Sungai } \\
\text { Limau Rakit } \\
\text { Kulim sub- } \\
\text { district }\end{array}$ \\
\hline & $\begin{array}{l}\text { Okupasi oleh } \\
\text { PT. Regunas } \\
\text { Agri Utama } \\
\text { (PT. RAU) }\end{array}$ & 10.000 ha & $\begin{array}{l}\text { Talang Durian } \\
\text { Cacar village } \\
\text { and Talang } \\
\text { Perigi, village } \\
\text { of Talang } \\
\text { Selantai Rakit } \\
\text { Kulim sub- } \\
\text { district }\end{array}$ \\
\hline & $\begin{array}{l}\text { Occupation } \\
\text { by Bukit } \\
\text { Betabuh Sei } \\
\text { Indah Ltd } \\
\text { (PT. BBSI) }\end{array}$ & 13.450 ha & $\begin{array}{l}\text { Talang Tujuh } \\
\text { Buah Tangga } \\
\text { village, Rakit } \\
\text { Kulim sub- } \\
\text { district } \\
\text { Indragiri Hulu } \\
\text { district, Riau }\end{array}$ \\
\hline 2005 & $\begin{array}{l}\text { Occupation } \\
\text { by Inecda } \\
\text { Plantation, } \\
\text { Ltd }\end{array}$ & 3.200 ha & $\begin{array}{l}\text { Rakit Kulin } \\
\text { sub-district }\end{array}$ \\
\hline 2007 & $\begin{array}{l}\text { Occupation } \\
\text { by Bukit } \\
\text { Betabuh Sei } \\
\text { Indah Ltd } \\
\text { (PT. BBSI) }\end{array}$ & 13.450 ha & $\begin{array}{l}\text { Kecamatan } \\
\text { Peranap sub- } \\
\text { district and } \\
\text { Rakit Kulim } \\
\text { Inhu }\end{array}$ \\
\hline 2013 & $\begin{array}{l}\text { Land } \\
\text { remained for } \\
\text { Talang } \\
\text { mamak } \\
\text { indigenous } \\
\text { community }\end{array}$ & 2.300 ha & $\begin{array}{l}\text { Sub-districts of } \\
\text { Peranap and } \\
\text { Rakit Kulim } \\
\text { Inhu }\end{array}$ \\
\hline
\end{tabular}

Source: Data of Research Analysis, 2019.

${ }^{7}$ Ibid., p. 104-107
There are four customary forest areas; 330,933 hectares of river, 98,577 hectares of Durian Cacar forest, and 21,901 hectares of Kelumbuk Tinggi Baner forest ${ }^{8}$. The forest area spread in Rakit Kulim and Rengat Barat Districts which total area is 451,411 hectares. However, Mongabay Indonesia's report which conducted an empirical study stated that in 2013 there were only 2,300 hectares of Talang Mamak forest, which is approximately 20 percent of the total customary forest area, 2,300 hectares of this area functioned for six thousand people. This 2,300 hectare area also includes a count of the buffer zones of Bukit Tiga puluh National Park. In an interview of Mongabay Indonesia with Talang Mamak indigenous young man named Abu Sanar, "just taking wood for home is now being held by officers"9.

In its journey from 2000 to 2007, the community continued seeking ownership rights of their customary lands to the government continuously making demands on the accountability of private companies that grabbed their customary forests. But in 2008 to 2013, there was no longer any resistance from the community over private companies and the government, while the Talang Mamak Customary Forest area continued to decrease. As in 2013 there were only 2,300 hectares, compared to 2007 people who continued to demand 49,100 hectares of forest rights, but in 2013, only

\footnotetext{
8 Kompas.com. Talang Mamak dan Masyarakat Adat yang Merana. Accessed from http://sains.kompas.com/read/2010/04/03/232047 93/Talang.Mamak.dan.Masyarakat.Adat.yang.Mera na on December 17, 2018, at 13.00 WIB

${ }^{9}$ MongabayIndonesia.com. Talang Mamak Hak Ulayat Musnah Diterjang Budaya Uang. Accessed from http://www.mongabay.co.id/2013/01/19/talangmamak-hak-ulayat-musnah-diterjang-budaya-uang/ on December 17, 2018, at 13.20 WIB
} 
2,300 hectares remained. This means that throughout 2013 until 2017, the community has lost 400,011 hectares of land. However, the conflict was not so prominent in the media as in previous years. So the question is, what kind of compromise or transaction occurred in 2007 to 2013 ?

\section{The role change : Indigenous Chief to be Cukong or Broker}

The decision-making system in Talang Mamak indigenous people is through customary deliberations. Decision making through this system is to determine all matters of a general nature, such as the management of pool prohibition, management of communal land, both in the rules of management and determination of harvest time. Communities can take actions regarding the use of customary forests under Indigenous Chief supervision. The chief position is important even it confirmed in their adage "better to die children than customary death" which means that the position of customary is at the top of the hierarchy. Elected leader is not descendants of ordinary people, but descended from previous traditional leaders.

From 2000 to 2007, all Patih, Talang Mamak indigenous Chief, and the people felt that they shared a common enemy, but a private company that grabbed their land, various resistance efforts were made to demand the return of Talang Mamak customary forest. From 2007 to 2013, the large number of forests lost and turned into oil palm plantations no longer gave birth to resistance from the community as happened in 2000. Based on collected sources, both from newspapers and simple interviews with one colleagues who visited to examine the life patterns of the Talang Mamak in one village. Son of one of the Indigenous Chiefs acknowledged that his father's profession in addition to being the
Indigenous Chief was also a cukong or broker who sold customary land to private companies. This is to survive because every year the number of customary forests lost due to being seized by private companies is increasingly widespread. Herbert Spencer explained social change and related it to the Theory of Evolution put forward by Darwin, Spencer explained in social interaction, change would always exist and be dynamic, change would start from the tribal stage which is hegemony and simple to modern and complex stages of society. In line with what Darwin said, Spencer argued that the strongest would be the one who won, who was capable and passionate and able to adapt to changes that would win the struggle for life, weak people would be marginalized and marginalized ${ }^{10}$.

Patih Gading, the grandson of Patih Laman who is now the successor to the chief of the Talang Mamak, explained that the forest has been a victim of greedy people who do not care about the environment. As stated in the Commander's Oligarchy theory by Jeffrey A. Winters, within the customary structure there is the Customary Chairperson whose initial is Patih "Y" and several people who are included in his alliance to trade customary forests, participate in this group Durian Cacar Village Head initials " $H$ ". The mechanism is that the Village Head makes a document regarding the ownership of recognized customary land through the signature of Patih "Y" who is also the grandson of Patih Laman, then the results of $j$ transactions carried out with private companies are not distributed to the public but are enjoyed by groups this group.

10 Herbert Spencer. 1896. Principles of Sociology, in Aminudin Ram. 1992. Sosiologi. Jakarta: Erlangga. p. 208

Copyright (C) 2019. Owned by Author(s), published by Society. This is an open-access article under CC-BY-NC-SA license. https://doi.org/10.33019/society.v7i1.78 
Although the consequences of the actions were dismissal as chief by King Indragiri on charges of betraying customary oaths on inheritance debts, the reality that occurred in the field, the position of Patih "Y" was still very strong and could not be prevented from the trading. Even the community that is also a community of the Talang Mamak who are members of the sale and purchase of this land is increasing. Patih Laman also reported the case of trading to the police, but it had no continuation, while the practice of customary forest trade and purchase continued. This has an impact on the overlapping of land ownership, on the one hand private companies feel that they have carried out customary forest sale and purchase transactions with the community, so that customary forests changed ownership ${ }^{11}$.

\section{Private Companies and Talang Mamak Indigenous Community Compromises}

People who realize that the resistance efforts carried out so far have only been in vain because there is no settlement from the company on their demands, plus some of the land they consider has been taken over by the private companies actually has official ownership documents that are endorsed by The Indigenous Chief and village head who has changed roles as a broker. So, by comparing the dynamics of the conflict that occurred in 2000 to 2008 and thereafter, from 2008 to 2013, the conflicts that occurred in 2008 to 2013 were no longer related to the return of customary forests, but demands for compensation or compensation money. This means that most people choose to compromise the situation that has occurred. The compromise that occurs is: First, companies that have planted

${ }^{11}$ Jhony Setiawan, op.cit, p. 3 oil palm seedlings in customary forests of the Talang Mamak indigenous will pay compensation for customary forests use. Second, the company will buy community land and then exchange it with one oil palm plot, which can then be sold to the company when the harvest period arrives ${ }^{12}$.

Compromise happened because the community felt that it was the only way that was felt most likely to survive in the midst of greater power control, because the resistance effort was unable to deal with the strength of the company. As stated by Spencer, a person or group must be strong in order to survive and adapt to change, known as the concept of survival of the fittes.

Nevertheless, there are still groups that continue to try to maintain their customary forests such as a group of indigenouss named Tiga Balai under Patih Laman, in order to fight for rights to customary forests. They reject and oppose all forms of development and are willing to die to defend the forest. The reason they maintain their customary land is due to the narrowing of the environment of Talang Mamak forest which has an impact on the difficulty of carrying out a farming system and must adapt, for those who are unable to adapt their lives will be threatened ${ }^{13}$.

The company and capital owners made an offer under the pretext of wanting to prosper the Talang Mamak indigenous community. They persuaded that customary lands and forests be submitted for processing. In this case, of course the indigenous people did not agree with the

12 MongabayIndonesia.com. Beginilah Nasib Masyarakat Adat Talang Mamak Bagian 1. Accessed from http://www.mongabay.co.id/2016/07/24/beginilahnasib-masyarakat-adat-talang-mamak-bagian-1/ on

December 15, 2018, at 21.30 WIB

13 Ibid., p. 16

Copyright (C) 2019. Owned by Author(s), published by Society. This is an open-access article under CC-BY-NC-SA license. https://doi.org/10.33019/society.v7i1.78

31 
offer, but the private companies continued their efforts by approaching the Customary Chair and the Village Head. Because of this, society is divided into two parts; First, the community agreed to the company's offer and Secondly, the community refused to approve and continue to try to defend Customary Forest. Because of the divisions that occurred in the bodies of indigenous peoples and also traditional elders, the company took advantage of this situation and then freely obtained the approval of individual indigenous chief and Village Heads. Then for this reason, private companies and owners of capital submitted permits to the government, saying they had obtained the consent of indigenous peoples. Even though the agreement in question is only the approval of the Indigenous Elders and the Village Head and not through customary deliberations ${ }^{14}$.

\section{Private Companies presence and Poor Government Roles to protect customary forest}

Land is very important for indigenous people since it contains many important things to support themselves, such as economic resources, identity, selfdetermination and their cultural interests ${ }^{15}$. In the Universal Declaration of Human Rights (UDHR) Article 17 guarantees rights to property, including land. Specifically regarding the issues of indigenous peoples, several international legal mechanisms guarantee access of indigenous peoples to their lands through Article 13 to Article 19

\footnotetext{
14 Ibid.,

15 Gilbert, J. 2007. Indigenous Peoples' Land Rights Under the International Law: From Victims to Actors. Leiden: Martinus Nijhoff. p. Xv-xvi in Dini Suryani Structural Violation Of Indigenous Human Rights In Indonesia: A Case Study Of Merauke Integrated Food And Energy Estate (Mifee) In Papua. Journal of society and Culture, Volume 18 No. 1 year 2016, p.100
}

of the ILO Convention 1989. Regulated also in the United Nations Declaration on the Rights of Indigenous Peoples (UNDRIP), in article 8 , paragraph $2 \mathrm{~b}$ ) stipulates that states must be responsible for providing effective instruments to prevent any action, which causes the disposal of land, territories and resources of indigenous peoples. Added in article 10, the declaration guarantees that indigenous peoples cannot be forcibly transferred from their lands and territories, and that no relocation occurs without their free, prior prior approval. The act of relocation must also provide fair compensation and the possibility to return. Then, through articles 25 and 26, the declaration recognizes the spiritual and cultural relations between indigenous peoples and traditional lands that have been owned, occupied or used. Based on these provisions, the state must provide legal recognition and protection of these lands and resources with respect to traditions, customs, and ownership systems that are owned by indigenous peoples ${ }^{16}$.

Based on Schutter report on the right to food to the United Nations, he came to the conclusion that indigenous peoples were vulnerable to the seizure of large-scale land in the world. In a larger domain such as Southeast Asia, Magallanes \& Hollick shows that as the most vulnerable group in society, indigenous peoples have suffered a lot from the influence of development in Southeast

\footnotetext{
16 Schutter, O. d. (2009, June 11). Large-scale land acquisitions and leases - Special Report on the Right To Food. Retrieved October 31, 2014 from Organisation for Economic Co-operation and Development: http://www.oecd.org/site/swacmali2010/44031283. pdf, p 8, in Dini Suryani. Structural Violation of Indigenous Human Rights In Indonesia: A Case Study Of Merauke Integrated Food And Energy Estate (Mifee) In Papua. Journal of Society and Culture, Volume 18 No. 1 year 2016 p. 100
} 
Asia, which has taken the form of losing their land ${ }^{17}$.

The loss of the customary forests in addition to land grabbing carried out by private companies was also supported by the poor performance of the Indragiri Hulu the local government to save the rights of the indigenous community over their forests. Hundreds of times people complained about the land grabbing problems they faced to Regional House of Representatives (DPRD) Indragiri Hulu but none of the cases were resolved. This requires more in-depth and comprehensive research on whether the Regional Government of Indragiri Hulu Regency is involved in a compromise with private companies.

In 2006, the Regional Government of Indragiri Hulu Regency was scheduled to strengthen the legal umbrella for the customary forests of Talang Mamak through Regional Regulations. The regent of Indragiri Hilir and the Chairperson of the Indragiri Hulu DPRD agreed on a Joint Agreement Letter (SKB) Number 31 of 2006 concerning the Indigenous Forest of the indigenous community. However, since the decree was signed, there has never been a continuation of the regional regulation. There is no concrete evidence for the implementation of the SKB. The Indragiri Hulu Regency Government does not care about land grabbing that continues to occur $^{18}$.

17 Magallanes, C., \& Hollick, M. (Eds.). 1998. Land Conflict in Southeast Asia: Indigenous People, Environment and International Law. Bangkok: White Lotus Press, p 6-7 in Dini Suryani Structural Violation Of Indigenous Human Rights In Indonesia: A Case Study Of Merauke Integrated Food And Energy Estate (Mifee) In Papua. Journal of society and culture, Volume 18 No. 1 year 2016 p. 101

18 Kompas.com. Punahnya Hutan Suku Talang Mamak. Accessed from
Report from the letter, the Indragiri Hulu Government only recognized the rights of the Talang Mamak indigenous which included rights to their customary forests on August 24, 201719. The government only acted when the customary forests of the Talang Mamak were already gone and cultures that had taken root in people's lives almost extinct because land grabbing happened.

\section{Conclusion}

Customary forests exploitation has destructed economy, environment, and water around the Indigenous people neighborhood. As a result, their life and culture has been changed, their customary wealth and existence extinct. The people who were very early on working as fishermen and farmers, conducting barter system as their ancestor doing. Nowadays, their indigenous chief has been a broker although he broke the customary law by trading the forest to private companies. Some people have been becoming oil palm farmers and working as laborers in the private companies. The changes, as Spencer states, must be done to survive. On the other hands, there are other people against the decision working at the companies, unfortunately the people work at the companies increased. In the year 2000 and 2007, the companies were public enemy, resisted the land grabbing, now they take and accept the companies presence. In the

http://nasional.kompas.com/read/2010/05/17/103 24076/Punahnya.Hutan.Suku.Talang.Mamak on December 15, 2018, at 20.00 WIB

19 Riauonline.com. Pemkab Indragiri Hulu Komitmen Akui Hak Adat Suku Talang Mamak. Accessed from http://www.riauonline.co.id/riau/read/2017/08/2 4/sejarah-pemkab-IndragiriHulu-komitmen-akuihak-adat-suku-talang-mamak on December 15, 2018, at 21.00 WIB

Copyright (C) 2019. Owned by Author(s), published by Society. This is an open-access article under CC-BY-NC-SA license. https://doi.org/10.33019/society.v7i1.78 
year 2008 until 2013 they worked at the companies to survive. The indigenous people did it since their efforts to claim the forest did not meet any good responses both from private companies and the local government of Indragiri Hulu district.

Even, in 2013, an NGO, has supported the people to return their rights on the land, however, did not solve the battle. The NGO, Mongabay Indonesia, only issued their findings related to the forest conditions. The zero action, both NGO, moreover environmental NGO, and the local government to return the indigenous rights on the forest, only aggravated the conflicts.

\section{References}

Court Decision Number 35/PUU-X/2012 about Constitutional Review Number 41 Year 1999 about Forestry in The 1945 State Constitution of the Republic of Indonesia. The Constitutional Court of the Republic of Indonesia. P. 102

Gilbert, J. (2007). Indigenous Peoples' Land Rights Under the International Law: From Victims to Actors. Leiden: Martinus Nijhoff, in Suryani, D. (2016). Structural Violation Of Indigenous Human Rights In Indonesia: A Case Study Of Merauke Integrated Food And Energy Estate (Mifee) In Papua. Jurnal Masyarakat dan Budaya, 18 (1), 97-109.

Gilung. (2012). Talang Mamak: Hidup Terjepit Di Atas Tanah dan Hutannya SendiriPotret Konflik Kehutanan Antara Masyarakat Adat Talang Mamak Di Kabupaten Indragiri Hulu, Provinsi Riau Dengan Industri Kehutanan. Presented as additional material witnesses on Constitutional Court Review No. 41 Year 1999 about Forestry in The 1945 State
Constitution of the Republic of Indonesia at Constitutional Court of the Republic of Indonesia, June 14, 2012.

Setiawan, J., et al. (2007). Laporan Final Penelitian: Analisa Konflik Pertanahan di Provinsi Riau Antara Masyarakat dengan Perusahaan. Research and Development Team FKPMR 2007.

Kompas.com. Punahnya Hutan Suku Talang Mamak. Accessed from http://nasional.kompas.com/read/2 010/05/17/10324076/Punahnya.Hut an.Suku.Talang.Mamak on December 15, 2018, at 20.00 WIB.

Kompas.com. Talang Mamak dan Masyarakat Adat yang Merana. Accessed from http://sains.kompas.com/read/2010 /04/03/23204793/Talang.Mamak.da n.Masyarakat.Adat.yang.Merana on December 17, 2018, at 13.00 WIB

Magallanes, C., \& Hollick, M. (Eds). (1998). Land Conflict in Southeast Asia: Indigenous People, Environment and International Law. Bangkok: White Lotus Press, dalam Suryani, D. (2016). Structural Violation Of Indigenous Human Rights In Indonesia: A Case Study Of Merauke Integrated Food And Energy Estate (Mifee) In Papua. Jurnal Masyarakat dan Budaya, 18 (1), 97-109.

MongabayIndonesia.com. Beginilah Nasib Masyarakat Adat Talang Mamak Bagian 1. Accessed from http://www.mongabay.co.id/2016/07/24/ beginilah-nasib-masyarakat-adat-talangmamak-bagian-1/ on December 15, 2018 , at $21.30 \mathrm{WIB}$

MongabayIndonesia.com. Talang Mamak Hak Ulayat Musnah Diterjang Budaya Uang. Accessed from http://www.mongabay.co.id/2013/ 01/19/talang-mamak-hak-ulayat- 
musnah-diterjang-budaya-uang/ on December 17, 2018, at 13.20 WIB

Pruitt, D. G., \& Rubin, J. Z. (2009). Teori Konflik Sosial. Yogyakarta: Pustaka Pelajar.

Riauonline.com. Pemkab Indragiri Hulu Komitmen Akui Hak Adat Suku Talang Mamak. Accessed from http://www.riauonline.co.id/riau/r ead/2017/08/24/sejarah-pemkabIndragiriHulu-komitmen-akui-hakadat-suku-talang-mamak on December 15, 2018, at 21.00 WIB

Schutter, O. d. (2009). Large-Scale Land Acquisitions and Leases-Special Report on the Right to Food. Retrieved October 31, 2014 From Organisation for Economic Co-operation and Development: http://www.oecd.org/site/swacmal i2010/44031283.pdf, in Suryani, D. (2016). Structural Violation of Indigenous Human Rights In Indonesia:
A Case Study Of Merauke Integrated Food And Energy Estate (Mifee) In Papua. Jurnal Masyarakat dan Budaya, 18 (1), 97-109.

Scott, J. C. (2000). Senjatanya Orang-Orang Yang Kalah, (Bentuk-bentuk Perlawanan Sehari-Hari Kaum Tani). Jakarta: Yayasan Obor Indonesia.

Spencer, H. (1896). Principles of Sociology, dalam Ram, A. (1992). Sosiologi. Jakarta: Erlangga

Sugiono. (2008). Memahami Penelitian Kualitatif. Bandung: IKAPI.

Winters, J. A. (2011). Oligarki. Jakarta: PT. Gramedia Pustaka Utama. 
1. Rizky Octa Putri Charin. A Master Degree student in Indonesian Politics at Department of Politics and Government, Gadjah Mada University, Yogyakarta, Indonesia. She obtained her Bachelor Degree in International Relations from University of Riau in 2016. Corresponding: kikycharin@gmail.com.

2. Arief Hidayat. A Master Degree student in Indonesian Politics at Department of Politics and Government, Gadjah Mada University, Yogyakarta, Indonesia. He obtained his Bachelor Degree in Government Affairs from Padjajaran University, Bandung, Indonesia in 2008. Corresponding: ariefcrbn@gmail.com. 